\title{
The fatty acid composition of cultured mussels (mytilus galloprovincialis lamarck 1819) in offshore longline system in the black sea
}

\begin{abstract}
The fatty acid (FA) composition was determined in the mussel (Mytilus galloprovincialis Lamarck 1819) cultured at the longline system located in Sinop (Black Sea) from October to September. Seasonal variation of lipid was significantly different throughout the study period; the highest value was in winter $(1.90 \pm 0.10 \%$ wet weight $)$ and the lowest value in spring $(1.45 \pm 0.22 \%)(\mathrm{p}<0.05)$. The polyunsaturated fatty acids (PUFAs) were dominant lipids in spring and winter including $55.80 \%$ and $55.63 \%$ of total lipids, respectively, while PUFAs in the summer and autumn were considerably higher than values in spring and winter, comprising $52.97 \%$ and $50.67 \%$ of total lipids, respectively. The palmitic acid (PA, 16:0) saturated fatty acids (SFAs), 11-eicosenoic acid (EA, 20:1n9) mono-unsaturated fatty acids (MUFAs), and docosahexaenoic acid (DHA, C22:6 n-3) PUFAs were the most dominant fatty acids of all. The results showed that all fatty acids were the PUFAs with the highest percentage. Within this group, the eicosapentaenoic acid (EPA, C20:5 n-3) and DHA fatty acids presented the highest levels. Also, the lowest and the highest $n-3 / n-6$ ratio were in autumn $(1.44 \%)$ and winter $(2.23 \%)$, respectively. These results suggest that spring was the more suitable period for collecting mussels and for healthy diet of humans.
\end{abstract}

Keywords: Black sea, Fatty acid composition, Mussel (Mytilus galloprovincialis)
Volume 2 Issue 6 - 2015

\author{
Seval Dernekbasi,' Abdullah Oksuz, ${ }^{2}$ Meryem \\ Yesim Celik,' Ismihan Karay,' Sedat Karay' \\ 'Department of Aquaculture, University of Sinop, Turkey \\ ${ }^{2}$ Department of Nutrition and Dietetics, University of \\ Necmettin Erbakan, Turkey
}

\author{
Correspondence: Seval Dernekba??, Department of \\ Aquaculture, Faculty of Aquaculture and Fisheries, University of \\ Sinop, 57000 Sinop, Turkey, Tel +903682876254, \\ Email sevalyaman@hotmail.com
}

Received: August 13,2015 | Published: October 14, 2015
Abbreviations: FAs, Fatty Acids, SFAs, Saturated Fatty Acids, MUFAs, Monounsaturated Fatty Acids, PUFAs, Polyunsaturated Fatty Acids, FAME, Fatty Acid Methyl Esters, GC-MS, Gas Chromatography-Mass Spectrometry, PA, Palmitic Acid $(16,0)$, POA, Palmitoleic Acid (16,1), VA, Cis-Vaccenic Acid (18,1n-7), OA, Oleic Acid (18,1n-9), LA, Linoleic Acid (18,2n-6), LNA, $\alpha$-Linolenic Acid (18,3n-3), ODA, Octadecatetraenoic Acid (18,4n3), EA, 11-Eikosenoik Asit (20,1n-9), EDA, Eicosadienoic Acid (20,2n-6), AA, Arachidonic Acid (20,4n-6), EPA, Eicosapentaenoic Acid (20,5n-3), DHA, Docosahexaenoic Acid (22,6 n-3), NMID, Non-Methylene-İnterrupted Dienoic Fatty Acids, AOAC, One Way Analysis of Variance, SD, Standard Deviation

\section{Introduction}

Mytilus galloprovincialis Lamarck 1819 is a marine mollusk with the highest ecological and economic importance in the Black Sea ecosystem. ${ }^{1}$ Among the Black Sea mussels the Black mussel $(M$. galloprovincialis) is the most widespread. Mussels are a filter feeding animal, which depends on phytoplankton, organic detritus, bacteria and probably dissolved organic matter in the water as sources of food. ${ }^{2}$ They are the most commonly cultured invertebrate organism and are among the most preferred wild collected species for consumption, which has been increasing considerably in recent years. ${ }^{3}$ Fatty acid composition in marine organisms is generally related with nutrients, season, water temperature and water depth. Therefore, it is well known that seasonal variations in lipid contents and fatty acid compositions of adult bivalves are closely linked to the reproductive cycle and climate changes and are affected by the availability and composition of the natural diet. ${ }^{4-6}$ In recent years, due to the imp act on health and its nutritional value, the importance of fatty acids has been striking. In particular, consumption of marine products rich with EPA and DHA as n-3 PUFA has positive impact on cardiovascular and inflammatory diseases, migraine type headaches, joint rheumatism, certain types of cancers, high blood pressure, diabetes, certain types of allergies and eye retina development. ${ }^{7,8}$ In human nutrition, fatty acids such as linoleic (LA, 18:2n-6) and $\alpha$-linolenic acids (LNA, 18:3n-3), which cannot be synthesized by the organism are essential. Therefore, they must be present, especially LA and LNA, in the diets for optimal growth and health. ${ }^{9,10}$ These dietary essential fatty acids can be desaturated further and elongated to form the physiologically essential C20 and C22 PUFA, arachidonic acid (AA, 20:4n-6), EPA and DHA. ${ }^{10}$

The food quality is a determinative factor for the growth of mussels, and microalgae are the major fatty acid source for bivalve molluscs. ${ }^{11}$ The palmitoleic acid (PA, 16:1n-7) fatty acid is considered to be a diatom marker, whereas oleic acis (OA, 18:1n-9) is not limited to a single phytoplankton group. ${ }^{12}$ Bivalve molluscs directly transform primary productivity in water to meat and their consumption as a human food is recommended due to the low amount of fat and high amount of protein they have. ${ }^{13}$ Increased intake of a variety of shellfish should be encouraged to provide a healthy diet, because shellfish are low in fat, especially low in saturated fat, contain the omega- 3 fatty acids, are excellent protein sources, and are especially good sources of iron, zinc, copper, and vitamin B12. ${ }^{14}$ Also, the best sources of PUFA are fish and crustacean. ${ }^{15-17}$

Mytilus galloprovincialis is an important commercial species in several zones of Mediterranean coasts. Despite the large amount of research devoted to characterizing the biology and ecology of $M$. galloprovincialis in the Black Sea in Sinop, ${ }^{18-21}$ information about its biochemistry is very rare. In marine bivalves, some polyunsaturated FAs (PUFAs) are important biochemical constituents, taking part in numerous biochemical processes and representing an energy supply under critical nutritional conditions. ${ }^{6}$ Therefore, the aim of this study 
was to examine the seasonal variations in lipid and the fatty acid (FA) composition and concentration in Mytilus galloprovincialis cultured at the longline system (Black Sea). It is also important that this study is going to be the first research relating to the determination of fatty acid profiles of cultured mussel in Black Sea.

\section{Materials and methods}

\section{Sample collection and treatment}

The study was carried in Sinop at a depth of 25-27 $\mathrm{m}$ at an offshore site in the Black Sea region between October 2009 and September 2010. The system was established at $10 \mathrm{~m}$ below the water surface to maintain the system against strong currents and waves. (Coordinates of culture system, at $42^{\circ} 01^{\prime} 30^{\prime \prime} \mathrm{N}-35^{\circ} 12^{\prime} 85^{\prime \prime}$ E). The 50-m-long mainline and the anchor lines of the system comprised 32-mm diameter polypropylene rope. The mussels were cultured in this submersible longline system in Sinop and growed on natural feed in the environment. Experimental mussels with the average length of $48.58 \pm 0.86-77.52 \pm 0.86 \mathrm{~mm}$ and the average weight of $11.01 \pm 0.47$ $42.18 \pm 4.51 \mathrm{~g}$ were collected from the culture ropes. Monthly triplicate mussel samples were taken by divers. The mussels were transferred to the laboratory into a 50-L tank filled with sea water and cleaning the mussels to ensure no contamination from fouling organisms. Then, their shells were opened by cutting the adductor muscles of mussels and mussel meats were homogenized. The homogenized mussel meats were stored at $-80^{\circ} \mathrm{C}$ in air-tight bags until they were analyzed.

\section{Biochemical analysis}

The total lipids were extracted following the method of Bligh and Dyer. ${ }^{22}$ The other chemical compositions of the mussel meats were analyzed by standard methods: $:{ }^{23}$ dry matter after drying at $105^{\circ} \mathrm{C}$ for $24 \mathrm{~h}$, crude protein by the Kjeldahl method after acid digestion $(\mathrm{N} \mathrm{x}$ 6.25) and ash by incineration at $550^{\circ} \mathrm{C}$ in a muffle furnace for $12 \mathrm{~h}$. All chemical analyses were carried out in triplicate.

\section{Preparation of fatty acid methyl esters}

To prepare fatty acid methyl esters of the mussel meats, approximately $30-35 \mathrm{mg}$ of lipid was saponified with $1.5 \mathrm{ml}$ of 0.5 $\mathrm{N}$ methanolic $\mathrm{NaOH}$ for $7 \mathrm{~min}$ at $115{ }^{\circ} \mathrm{C}$. After cooling, $2 \mathrm{ml}$ of $\mathrm{BF}$ $3 \%$ was added and heated for another $5 \mathrm{~min}$ at the same temperature mentioned above. Then reaction tubes were cooled, $2 \mathrm{ml}$ of iso-octane and $3 \mathrm{ml}$ of saturated $\mathrm{NaCl}$ solution were added, and mixed for 30 second then allowed to separate organic phase. Fatty Acid Methyl Esters (FAME) were extracted from the top layer, and transferred into the amber vial for further gas chromatography (GC) analysis. FAME extracts were kept at the freezer at $-20{ }^{\circ} \mathrm{C}$ until GC analysis. ${ }^{24}$

\section{Chromatographic conditions}

Fatty acids were analysed with GC-MS (Gas ChromatographyMass Spectrometry) using a Hewlett Packard GC (model 6890) and coupled with Hewlett Packard (model 5972A, HP 6890 system) MS detector. Separations of fatty acids were achieved with HPINNOWAX Polyethylene Glycol Capillary Column (Model number HP $19091 \mathrm{~N}-133,0.25 \mathrm{~mm} * 30 \mathrm{~m} * 0.25 \mu \mathrm{m})$ and HP 6890 automatic injection system was used. Injection and detector temperatures were set at $250{ }^{\circ} \mathrm{C}$ and $270{ }^{\circ} \mathrm{C}$, respectively. Split ratio was $1: 50$ with a total injection volume of $1 \mu \mathrm{l}$. Injector was washed three times with iso-octane and with the FAME containing isooctane prior to injection. Post injection, injector program was also set to triple wash of injector for next injection. Oven temperature was programmed initially at 120 ${ }^{\circ} \mathrm{C}$ and hold for 3 minutes. Then, the temperature was increased to 180
${ }^{\circ} \mathrm{C}$ and hold for 5 minutes, then increased to $250{ }^{\circ} \mathrm{C}$ with a $10{ }^{\circ} \mathrm{C}$ per minute ramp rate and hold at this temperature four for minutes. Total separation was achieved in 30 minutes. Identification of individual fatty acids was made by comparing those retention time of FAME standard (Supelco 47085U PUFA No: 3 ) and Supelco 37 component Fame mix (Supelco 47885-U). Confirmation of fatty acid methyl esters was also performed by using MS data base library (FAMEDBWAX). ${ }^{24}$

\section{Statistical analysis}

All biochemical analyses were done in triplicate and presented as mean values $\pm \mathrm{SD}$, after controlling for the normality and homogeneity of the data. The homogeneity of variance among the data was tested using Leven's test. Values for different fatty acids were expressed as a fraction (\%) of total identified fatty acids. Arcsine square root transformations of percentage data were conducted to achieve homogeneity of variances before applying statistical analysis. Whenever the assumptions of analysis of variance were not met, the Kruskal-Wallis ANOVA on ranks test was performed. Differences were considered significant at $p<0.05$. The Microsoft Office 2003 and Minitab 13.1 statistical package program were used for the analysis of the data. ${ }^{25}$

\section{Results}

\section{Biochemical compositions}

The biochemical composition of the mussel meats, expressed as percentage of protein, lipid and ash on the wet weight of mussel meat is shown in Figure 1. In general, high moisture contents were found in all samples (79.48-83.41\%). The protein content ranged from $7 \%$ (June) to $10 \%$ (October). The lower and higher protein concentration (9.42-12.43\%) were observed in June and October, respectively. The lipid percentage generally ranged from $2.08 \%$ to $0.99 \%$, with the highest value in December and the lowest value in June. The ash content of the meat reached peak values in June (1.70\%), coinciding with minimum lipid content. The ash content varied between $1.12 \%$ (April) and 1.70\% (June).
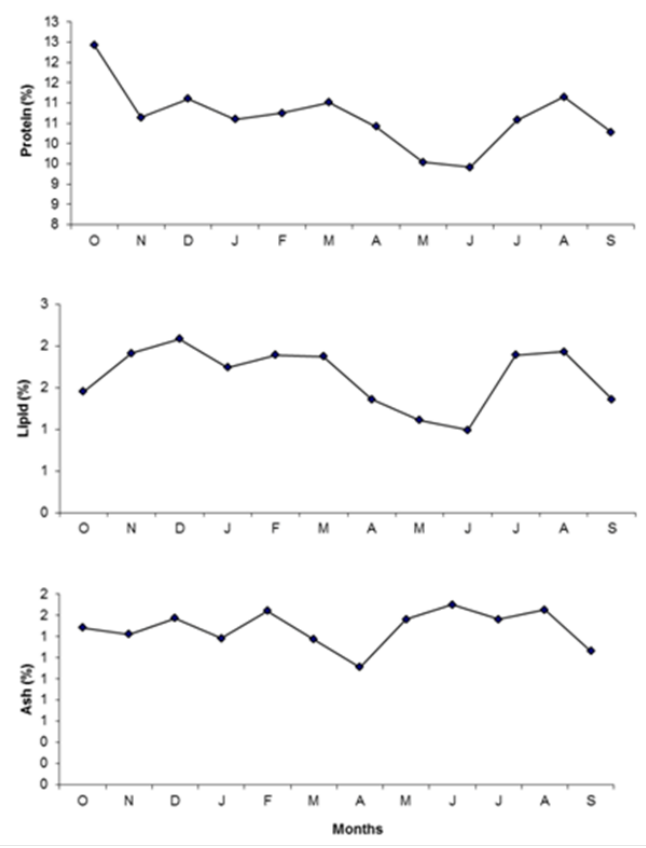

Figure I Monthly variations in protein, lipid and ash contents (\% of wet weight) of the mussels Mytilus galloprovincialis. 


\section{Fatty acid composition}

The fatty acid composition was identified for 27 classes by $\mathrm{GC} /$ MS. Table 1 showed the fatty acid composition in lipids for those classes. The dominant components of total fatty acids were PA, palmitoleic acis (POA, 16:1), EA, EPA and DHA. PA (17.71-20.86\%), EPA (7.97-13.35\%) and DHA (14.41-18.58\%) contained higher levels of fatty acids. The seasonal variations of the total saturated fatty acids varied between $25.66 \pm 0.75 \%$ (Spring) and $29.19 \pm 1.02 \%$ (Summer). The observed changes in the total saturated fatty acids were mostly due to the variability of PA and stearic acid (SA, 18:0) fatty acids (Table 1). Monounsaturated fatty acids varied between $15.06 \pm 1.23 \%$
(Winter) and $19.81 \pm 1.01 \%$ (Autumn), with the POA, oleic acid (OA, 18:1n-9c) and EA fatty acids showing the highest levels. Total polyunsaturated fatty acids, representing the majority of the total fatty acids, ranged from $50.67 \pm 0.59 \%$ (Autumn) to $55.80 \pm 1.29 \%$ (Spring). The proportions of n-3 PUFAs were higher than those of $n-6$ PUFAs and the most abundant of n-3 PUFAs were EPA and DHA fatty acids. EPA reached the highest level in winter $(13.35 \pm 3.26 \%)$, DHA reached the highest level in summer $(18.58 \pm 0.26 \%)$. The $\mathrm{n} 3 / \mathrm{n} 6$ ratio was determined between $1.44 \pm 0.03 \%$ (Autumn) and $2.23 \pm 0.19 \%$ (Winter). Statistical differences for fatty acid levels between months should be also given in Table 1 .

Table I Fatty acid composition (\% of total fatty acids (FAs)) of Mytilus galloprovincialis

\begin{tabular}{|c|c|c|c|c|}
\hline Fatty & Acids & Spring & Summer & Autumn Winter \\
\hline $\mathrm{Cl} 4: 0$ & $2.39 \pm 0.43^{a}$ & $2.24 \pm 0.17^{a}$ & $2.66 \pm 0.18^{\mathrm{ab}}$ & $3.55 \pm 0.60^{\mathrm{b}}$ \\
\hline CI5:0 & $0.52 \pm 0.03^{a}$ & $0.88 \pm 0.05^{b}$ & $0.87 \pm 0.04^{b}$ & $0.80 \pm 0.07^{b}$ \\
\hline $\mathrm{Cl} 6: 0$ & $|7.7| \pm 0.58^{\mathrm{a}}$ & $20.86 \pm 0.82^{b}$ & $18.94 \pm 2.17^{\mathrm{bc}}$ & $18.31 \pm 1.22^{\mathrm{ca}}$ \\
\hline CI7:0 & $I . I I \pm 0.1 I^{a}$ & $1.27 \pm 0.08^{a}$ & $1.27 \pm 0.15^{a}$ & $1.19 \pm 0.2 \mathrm{I}^{\mathrm{a}}$ \\
\hline C18:0 & $3.93 \pm 0.20^{\mathrm{a}}$ & $3.94 \pm 0.1 \mathrm{I}^{\mathrm{a}}$ & $4.7 \mathrm{I} \pm 0.43^{\mathrm{b}}$ & $3.26 \pm 0.07^{\mathrm{a}}$ \\
\hline ESFA & $25.66 \pm 0.75^{a}$ & $29.19 \pm 1.02^{b}$ & $28.45 \pm 2.07^{b}$ & $27.1 I \pm 0.84^{b}$ \\
\hline $\mathrm{Cl} 4: 1$ & $1.20 \pm 0.24^{\mathrm{a}}$ & $0.71 \pm 0.12^{b}$ & $0.88 \pm 0.19^{b}$ & $1.57 \pm 0.47^{\mathrm{a}}$ \\
\hline CI5:I & $0.45^{\mathrm{a}}$ & $0.31 \pm 0.04^{\mathrm{a}}$ & $0.47^{a}$ & nd \\
\hline CI6:In-7 & $4.75 \pm 1.02^{\mathrm{a}}$ & $2.92 \pm 0.26^{b}$ & $3.81 \pm 0.12^{b}$ & $5.24 \pm 1.29^{a}$ \\
\hline CI7:I & $1.35 \pm 0.18^{a}$ & $1.46 \pm 0.17^{\mathrm{a}}$ & $1.63 \pm 0.25^{a}$ & $2.05 \pm 0.98^{b}$ \\
\hline CI8:In-7 & $2.80^{\mathrm{a}}$ & $2.37^{\mathrm{a}}$ & $3.31^{\mathrm{a}}$ & nd \\
\hline CI8:In-9c & $3.01 \pm 0.90^{\mathrm{a}}$ & $3.39 \pm 0.18 a^{b}$ & $3.64 \pm 0.16^{b}$ & $2.83 \pm 0.39 c$ \\
\hline$C 20: \ln 9$ & $3.95 \pm 0.40^{\mathrm{a}}$ & $5.69 \pm 0.29^{b}$ & $6.08 \pm 0.44^{b}$ & $3.36 \pm 1.00^{\mathrm{a}}$ \\
\hline इMUFA & $\mid 7.5 I \pm I .08^{a}$ & $16.85 \pm 0.64 \mathrm{ac}$ & $\mid 9.8 \mathrm{I} \pm \mathrm{I} .0 \mathrm{I}^{\mathrm{b}}$ & $15.06 \pm I .23 c$ \\
\hline $\mathrm{Cl} 6: 2 \mathrm{n} 4$ & $1.85 \pm 0.14^{\mathrm{a}}$ & $2.39 \pm 0.09^{b}$ & $1.55 \pm 0.13 c$ & $1.35 \pm 0.06 c$ \\
\hline $\mathrm{CI} 6: 4 \mathrm{nI}$ & $\mathrm{I} .09 \pm 0.1 \mathrm{I}^{\mathrm{a}}$ & $0.85 \pm 0.02^{\mathrm{a}}$ & $0.85^{\mathrm{a}}$ & $2.72 \pm 0.26^{b}$ \\
\hline CI8:2n6c & $3.00 \pm 0.22^{\mathrm{a}}$ & $2.16 \pm 0.18^{a}$ & $3.57 \pm 1.45^{\mathrm{a}}$ & $1.56 \pm 0.28^{b}$ \\
\hline $\mathrm{Cl} 8: 3 \mathrm{n} 3$ & $1.91 \pm 0.32^{\mathrm{a}}$ & $1.73 \pm 0.12^{\mathrm{a}}$ & $1.61 \pm 0.19^{a}$ & $\mathrm{I} .37 \pm 0.29^{\mathrm{b}}$ \\
\hline $\mathrm{Cl} 8: 3 \mathrm{n} 6$ & $2.22 \pm 0.35^{\mathrm{a}}$ & $2.52 \pm 0.08^{\mathrm{a}}$ & $2.93 \pm 0.15^{a}$ & $1.62 \pm 0.02^{b}$ \\
\hline CI8:4n3 & $2.70 \pm 0.48^{a}$ & $\mathrm{I} .4 \mathrm{I} \pm 0.22^{\mathrm{b}}$ & $1.35 \pm 0.16^{b}$ & $\mathrm{I} .84 \pm 0.5 \mathrm{Ic}$ \\
\hline$C 20: 2 n 6$ & $4.5 I \pm 0.07^{a}$ & $5.18 \pm 0.22^{\mathrm{b}} \mathrm{c}$ & $4.90 \pm 0.4 I \mathrm{c}^{\mathrm{a}}$ & $4.0 \mathrm{I} \pm 0.30^{\mathrm{a}}$ \\
\hline$C 20: 3 n 3$ & $1.52 \pm 0.14^{\mathrm{a}}$ & $\mathrm{I} .74 \pm 0.1 \mathrm{I}^{\mathrm{b}}$ & $2.03 \pm 0.30^{b}$ & $1.52 \pm 0.10^{\mathrm{a}}$ \\
\hline$C 20: 3 n 6$ & I. $18 \pm 0.36^{a}$ & $0.90 \pm 0.03^{a}$ & $1.07 \pm 0.12^{\mathrm{a}}$ & $0.68^{b}$ \\
\hline$C 20: 4 n 6$ & $0.77 \pm 0.1 \mathrm{I}^{\mathrm{a}}$ & $0.55 \pm 0.10^{\mathrm{a}}$ & $1.23 \pm 0.57^{b}$ & $2.08 \pm 1.04^{b}$ \\
\hline C20:5n3 (EPA) & $|2.79 \pm 0.7|^{\mathrm{a}}$ & $8.25 \pm 0.3 \mathrm{I}^{\mathrm{b}}$ & $7.97 \pm 0.34^{b}$ & $13.35 \pm 3.26^{\mathrm{a}}$ \\
\hline$C 22: 4 n 6$ & $3.81 \pm 0.10^{a}$ & $3.66 \pm 0.26^{\mathrm{a}}$ & $3.86 \pm 0.28^{a}$ & $3.7 I \pm 0.30^{\mathrm{a}}$ \\
\hline$C 22: 5 n 6$ & $2.20 \pm 0.14^{a}$ & $2.14 \pm 0.1 \mathrm{I}^{\mathrm{a}}$ & $2.25 \pm 0.2 \mathrm{I}^{\mathrm{a}}$ & $2.28 \pm 0.06^{\mathrm{a}}$ \\
\hline$C 22: 5 n 3$ & $1.00 \pm 0.04^{\mathrm{a}}$ & $0.92 \pm 0.1 \mathrm{I}^{\mathrm{a}}$ & $\mathrm{I} .08 \pm 0.2 \mathrm{I}^{\mathrm{a}}$ & $1.31 \pm 0.06^{\mathrm{a}}$ \\
\hline $\mathrm{C} 22: 6 \mathrm{n} 3$ (DHA) & $15.26 \pm 0.95 \mathrm{ac}$ & $18.58 \pm 0.26^{b}$ & $|4.4| \pm 1.05^{\mathrm{a}}$ & $16.23 \pm 1.80 c$ \\
\hline 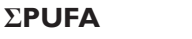 & $55.80 \pm I .29^{\mathrm{a}}$ & $52.97 \pm 0.74^{b}$ & $50.67 \pm 0.59 c$ & $55.63 \pm 1.66^{a}$ \\
\hline Total n-3 PUFA & $35.18 \pm 0.58^{\mathrm{a}}$ & $32.64 \pm 0.42^{\mathrm{b}}$ & $28.45 \pm 0.6 \mathrm{lc}$ & $35.61 \pm 0.95^{\mathrm{a}}$ \\
\hline Total n-6 PUFA & $17.68 \pm 0.72^{\mathrm{a}}$ & $17.10 \pm 0.87^{b}$ & $19.82 \pm 0.75 c$ & $15.95 \pm 0.60^{\mathrm{a}}$ \\
\hline$n-3 / n-6$ & $1.98 \pm 0.03^{a}$ & $1.91 \pm 0.02^{b}$ & $1.44 \pm 0.03 c$ & $2.23 \pm 0.19^{a}$ \\
\hline
\end{tabular}

Different superscripts within the row denote significant differences.

nd: Not Detected

\section{Discussion}

Depending on the temperature and weather conditions, marine invertebrates such as molluscs can undergo various changes in their lipid profiles owing to the activity of various enzymes. ${ }^{26}$ Differences in lipid profiles may also reflect the stage of development of mussel. ${ }^{27}$ The biochemical parameters in mussels are not only depending on climatic conditions, but also vary depending on the amount of nutrients in seawater and mussel reproductive cycle. ${ }^{28}$ Narváez et al. ${ }^{29}$ stated that the reason for variation in biochemical composition of mussel within a year can be because of the complex relationships between growth, reproduction and availability of food. According to the several studies, variation of biochemical composition of mussel (Mytilus edulis) within a year is related with gamete development. ${ }^{18,8}$
During gonad maturation, protein and lipid levels of body start to increase and continue until spawning. ${ }^{30}$ In the present study, there were significant variations in lipids throughout the year. Lipid content in spring were observed lower than in winter. Like lipid contents, protein contents of mussels changed throughout the year.

Zlatanos. ${ }^{31}$ reported that fatty acid composition and lipid contents are strongly related to the season and the geographical origin and Mytilus galloprovinciallis is an important nutritional source of the essential n-3 fatty acids during the whole year. Orban et al. ${ }^{32}$ stated that the increase in different planktonic populations did not affect lipid contents in mussels cultured in different regions, observed seasonal variation in saturated and unsaturated fatty acid levels was not statistically important but monounsaturated fatty acid 
levels significantly changed. Ventrella et al. ${ }^{17}$ reported that fatty acid composition of Mytilus galloprovincialis was significantly changed by differences between latitude and secondary feeding by natural nutrients which were related to geographical features. In this study, while the saturation level was quite stable from October to June, it increased in July, August and September and it was maximum in September. Based on this, unsaturation level was high throughout the year but decreased a little during autumn and spring. In the present study, among the fatty acids in total lipids, the saturated PA and the monounsaturated POA were the most abundant, whereas among polyunsaturated, the most abundant ones were EPA and DHA. Similarly, PA was one of the abundant fatty acids together with the polyunsaturated fatty acid of EPA and DHA in Mytilus edulis, ${ }^{12} \mathrm{M}$. galloprovincialis, ${ }^{32}$ Perna canalicus ${ }^{33}$ and Perna perna. ${ }^{29}$ As $20: 5 \mathrm{n}-3$ was consistently above $8 \%$, the mussels seemed to have remained in good condition throughout the present study.

Generally, marine organisms rich in n-3 fatty acid (especially EPA and DHA) are potentially important nutrient sources for human health These fatty acids show preventive effects against cancer, diabetes, cardiovascular and immune diseases. ${ }^{34}$ In the present study, nearly half of the fatty acid in mussels was PUFA and between $28.45 \pm 0.61$ $35.61 \pm 0.95 \%$ of the fatty acid was n-3 PUFA, while approximately $15.95 \pm 0.60-19.82 \pm 0.75 \%$ was $n-6$ PUFA. The predominant $n-3$ PUFA were EPA and DHA. Many marine species of molluscs are rich in EPA, with lower levels of Docosapentaenoic acid (DPA, 22:5n-3) and DHA. Other bivalve species, such as Ostrea lutaria and Crassostrea gigas, contain high levels of EPA and DHA, with the former being the predominant PUFA. Most shellfish, including mussels, are filter feeders, with their diets contains largely of plankton which provide n-3 fatty acids. Containing high ratio of DHA was explained by existence of various plankton and zooplankton species in the environment which are especially rich in DHA..$^{12,26,34-37}$ Prato et al. ${ }^{6}$ reported that SFA resulting from feeding are the most dominant fatty acid in $M$. galloprovincialis.

Falk Petersen et al. ${ }^{38}$ reported that the OA was a major fatty acid of most marine animal lipids and the $18: 1 \mathrm{n}-7$ fatty acid was also frequently present in great quantities, being derived from chain elongation of the phytoplankton PA fatty acid. For this reason, PA and cis-vaccenic acid (VA, 18:1n-7) in animal lipids tend to reflect phytoplanktonic dietary inputs, while OA reflects carnivorous dietary inputs. In this study, VA fatty acid was not detected in winter season but high amount of OA indicated an animal dietary input. On the other hand, the relatively high concentration of EA indicated once more that M. galloprovincialis feeds on zooplankton. Prato et al. ${ }^{6}$ reported that regarding the contribution of phytoplankton to the diet of M. galloprovincialis was very low, trophic markers for diatoms (PA and EPA) and those for dinoflagellates (Octadecatetraenoic acid (ODA, 18:4n-3) and especially DHA), suggested that diatoms and dinoflagellates contribute less to the diets of M. galloprovincialis than do other phytoplankton groups. However, in this study, trophic markers for diatoms (PA and EPA) and those for dinoflagellates (ODA and especially DHA) were determined at high ratios.

It is known that bivalves have no or only a very limited capability of synthesizing PUFAs, ${ }^{31,39,40}$ but seem to have the capability of de novo synthesis of some peculiar fatty acids called non-methyleneinterrupted dienoic (NMID) fatty acids (20:2 and 22:2) ${ }^{41}$ Molluscs have active fatty elongation and desaturating systems allowing the de novo synthesis of NMID fatty acids. These are the only polyunsaturated acids that are synthesized by marine molluscs. Some authors have claimed that these fatty acids in aquatic invertebrates have an endogenous origin..$^{41,42}$ It is possible that in the deficiency of dietary unsaturated fatty acids, including both n-3 and n- 6 fatty acids, the molluses synthesize NMID fatty acids to support the necessary fluidity of the cell membrane. Ackman ${ }^{43}$ have suggested that NMID fatty acids may be acceptable as mimics for the eicosadienoic acid (EDA, 20:2n-6) acid more commonly found in molluscs. ${ }^{42}$ In the present study, EDA fatty acid was detected at quite high rates from $4.01 \%$ to $5.18 \%$. The compositions of $20: 4,20: 5,22: 5$, and $22: 6$ are specific for aquatic organisms, ${ }^{44}$ Uno et al. ${ }^{44}$ reported that the compositions of $20: 4,20: 5,22: 5$ and $22: 6$ were $20-33 \%$ in total fatty acids. In the present research, high levels of n-3 PUFAs, low levels of n-6 PUFAs and high n-3/n-6 ratio values, especially in winter season were determined whereas the similar ratios were reported in spring season by Ventrella et al. ${ }^{17}$ Mytilus galloprovincialis fatty acid composition was reported to significantly change, probably due to the difference between latitudes and the secondary the nutrition with natural bait as connected to the geographical characteristics.

\section{Conclusion}

Inconclusion, fattyacidcomposition of M.galloprovincialis suggests that it would be an excellent source of n-3 fatty acids, especially EPA and DHA. In addition to this, seasonal variability observed in nutrient levels were characterised by low lipid contents throughout the year. In particular, the mussel tissues were determined to contain high levels of n-3 polyunsaturated fatty acids and low levels of n-6 polyunsaturated fatty acids. Also, the data obtained from present study may be used to future comparative studies of cultured area. The results will be useful to indicate the periods of the year that are more suitable for the marketing and consumption of mussels in the Sinop region. Data on the biochemical and fatty acid composition of $M$. galloprovincialis obtained in this study demonstrate that it is a high quality seafood product and the most suitable period of the year for its consumption is spring and winter seasons.

\section{Acknowledgements}

This study was supported by the TUBITAK- Scientific and Technological Research Council of Turkey. We thank The Scientific and Technological Research Council of Turkey (TUBITAK) for providing financial support.

\section{Conflicts of interest}

None.

\section{References}

1. Petrova E, Stoykov St. Distribution of the black mussel Mytilus galloprovincialis (L.) along the Bulgarian Black Sea coast. Agricultural Science and Technology. 2011;3(4):368-373.

2. Petrova E, Stoykov St. Investigations of Some Bivalve mollusks in Bourgas Bay (Bulgarian Balck Sea Coast). Macedonian Journal of Animal Science. 2011;1(1):223-226.

3. Arıman H, Düzgünes E. Doğu Karadeniz'de (Trabzon) sal sisteminde ip kolektörlerle midye (Mytilus galloprovincialisLam., 1819) spatlarının toplanmas1. Ege Üniversitesi Su Ürünleri Dergisi. 2004;21(1-2):443447.

4. Fernandez-Reiriz MJ, Labarta U, Babarro JMF. Comparative allometries in growth and chemical composition of mussel (Mytilus galloprovincialis, Lmk.) cultured in two zones in the Ria Sada (Galicia, N.W. Spain). Journal of Shellfish Research. 1996;15:349-353.

5. Caers M, Coutteau P, Sorgeloos P. Impact of starvation and of feeding algal and artificial diets on the lipid content and composition of juvenile oysters (Crassostrea gigas) and clams (Tapes philippinarum). Marine Biology. 2000;136(5):891-899.

6. Prato E, Danieli A, Maffia M, et al. Lipid and Fatty Acid Compositions of Mytilus galloprovincialis Cultured in the Mar Grande of Taranto (Southern Italy): Feeding Strategies and Trophic Relationships. Zoological Studies. 2010;49(2):211-219. 
7. Nettleton JA. Seafood nutrition in the 1990's, issues fort he consumer. İn: Graham Bligh (Ed.), Seafood science and tecnology, Inst of Fish Tech, Uni of Nova Scotia Halifax, Canada. 1992;p.32-39.

8. Gorga C. Quality assurance of seafood. Published by Van Nostrand Reinhold, New York, USA. 1998;pp.245.

9. Martino RC, Cyrino JEP, Portz L, et al. Performance and fatty acid composition of surubim (Pseudoplatystoma coruscans) fed diets with animal and plant lipids. Aquaculture. 2002;209(1-4):233-246.

10. Tocher DR. Metabolism and functions of lipids and fatty acids in teleost fish. Reviews in Fisheries Science. 2003;11(2):107-184.

11. Parrish CC, McKenzie CH, MacDonald BA, et al. Seasonal studies of seston lipid in relation to microplankton species composition and scallop growth in South Broad Cove, Newfoundland. Marine Ecology Progress Series. 1995;129:151-164.

12. Alkanani T, Parrish CC, Thompson RJ, et al. Role of fatty acids in cultured mussels, Mytilus edulis, grown in Notre Dame Bay, Newfoundland. Journal of Experimental Marine Biology and Ecology. 2007;348(1-2):33-45.

13. Çulha ST. Karadeniz'de batırılmış uzun halat sisteminde yetiştirilen midyelerdeki iz element seviyeleri. Doktora tezi, Sinop Üniversitesi Fen Bilimleri Enstitüsü, Sinop. 2011.

14. Dong FM. The nutritional value of shellfish. School of Aquatic and Fiahery Sciences. University of Washington Seattle, Washington, USA. 2001;p.8.

15. Pigott GM, Tucker BW. Seafood effects of technology on nutrition. CRC PRess, New York, USA. 1990;pp.359.

16. Kyriazi-Papadopoulou A, Vareltzis K, Bloukas JG, et al. Effect of smoking on quality characteristics and shelf-Life of mediterranean mussel (Mytilus galloprovincialis) meat under vacuum in chilled storage. Italian Journal of Food Science. 2003;15(3):371-381.

17. Ventrella V, Pirini M, Pagliarani A, et al. Effect of temporal and geographical factors on fatty acid composition of $M$. galloprovincialis from the Adriatic sea. Comp Biochem Physiol B Biochem Mol Biol. 2008;149(2):241-250.

18. Karayücel S, Erdem M, Uyan O, et al. Spat settlement and growth on long-line culture system of the mussel, Mytilus galloprovincialisin the Southern Black Sea. The Israeli Journal of Aquaculture-Bamidgeh. 2002;54(4):163-172.

19. Karayücel S, Karayücel I, Erdem M, et al. rowth and production in longline cultivated Mediterranean mussel (Mytilus galloprovincialis) in Sinop, Black Sea. The Israeli Journal of Aquaculture-Bamidgeh. 2003;55(3):169-178.

20. Karayücel S, Çelik MY, Karayücel I, et al. Growth and production of raft cultivated mediterranean mussel (Mytilus galloprovincialis Lamarck, 1819) in Sinop, Black Sea. Turkish Journal of Fisheries ans Aquatic Sciences. 2010;10:9-17.

21. Karayücel S, Çelik MY, Karayücel I, et al. Effects of stocking density on survival, growth and biochemical composition of cultured mussels (Mytilus galloprovincialis, Lamarck 1819) from an offshore submerged longline system. Aquaculture Research. 2015;46(6):1369-1383.

22. Hanson SWF, Olley J. Application of the Bligh and Dyer method of lipid extraction to tissue homogenates. Biochemical Journal. 1963;89:101102.

23. AOAC. Official methods of analysis, 16th (edn), Association of Official Analytical Chemists, Arlington, USA. 1995.

24. Öksüz A, Özyılmaz A. Changes in Fatty Acid Compositions of Black Sea Anchovy (Engraulis encrasicolus L. 1758) During Catching Season. Turkish Journal of Fisheries ans Aquatic Sciences. 2010;10(3):381-385.

25. Gardiner WP. Statistics fort he Bioscience. Prentice Hall Europe, Great Britain, UK.1997;pp.416.

26. Murphy KJ, Money BD, Mann NJ, et al. Lipid FA, and sterol composition of New Zealand gren lipped mussel (Perna canaliculus) and Tasmanian blue mussel (Mytilus edulis). Lipids. 2002;37(6):587-595.

27. Gabbott RA. Energy metabolism. In: Bayne BL (Ed.), Cambridge University Press, USA. 1976;pp.293-355.

28. Lachance AA, Myrand B, Tremblay R, et al. Biotic and abiotic factors influencing attachment strength of blue mussels Mytilus edulis in suspended culture. Aquatic Biology. 2008;2:119-129.

29. Narváez M, Freites L, Guevara M, et al. Food availability and reproduction affects lipid and fatty acid composition of the brown mussel, Perna perna, raised in suspension culture. Comp Biochem Physiol B Biochem Mol Biol. 2008;149(2):293-302.

30. Lachowicz JS. Population biology of mussels (Aulacomya maoriana, Mytilus galloprovincialis and Perna canaliculus) from rocky intertidal Shores in Wellington Harbour, New Zealand. 2005.

31. Ventrella V, Pirini M, Pagliarani A, et al. Effect of temporal and geographical factors on fatty acid composition of M. galloprovincialis from the Adriatic sea. Comp Biochem Physiol B Biochem Mol Biol. 2008;149(2):241-250.

32. Orban E, DiLena G, Nevigato $T$, et al. Seasonal changes in meat content, condition index and chemical composition of mussels (Mytilus galloprovincialis) cultured in two different Italian sites. Food Chemistry. 2002;77(1):57-65.

33. Taylor AG, Savage C. Fatty acid composition of New Zealand greenlipped mussels, Perna canaliculus: Implications for harvesting for n-3 extracts. Aquaculture. 2006;261(1):430-439.

34. Sağlik S, İmre S. Fatty acid composition and cholesterol content of mussel and shrimp consumed in Turkey. Turk $J$ Mar Scienc. 1997;3(3):179-189.

35. Freites L, Fernández-Reiriz MJ, Labarta U. Fatty acid profiles of Mytilus galloprovincialis (Lmk) mussel of subtidal and rocky shore origin. Comp Biochem Physiol B Biochem Mol Biol. 2002;132(2):453-461.

36. Mclean CH, Bulling KR. Differences in lipid profile of New Zealand marine species over four seasons. Journal of Food Lipids. 2005;12(4): 313-326.

37. Dridi S, Romdhane MS, Elcafsi M. Seasonal variation in weight and biochemical composition of the Pacific oyster, Crassostrea gigas in relation to the gametogenic cycle and environmental conditions of the Bizert lagoon, Tunisia. Aquaculture. 2007;263(1-4):238-248.

38. Falk-Petersen S, Hagen W, Kattner G, et al. Lipids, trophic relationships, and biodiversity in Arctic and Antarctic krill. Canadian Journal of Fisheries and Aquatic Sciences. 2000;57(3):178-191.

39. Waldock MJ, Holland DL. Fatty acid metabolism in young oysters, Crassostrea gigas: polyunsaturated fatty acids. Lipids. 1984;19(5):332-336.

40. Chu FLE, Graeves J. Metabolism of palmitic, linoleic, and linolenic acids in adult oysters, Crassostrea virginica. Marine Biology. 1991;110(2):229-236.

41. Zhukova NV. The pathway of the biosynthesis of nonmethyleneinterrupted dienoic fatty acids in molluscs. Comp Biochem Physiol B Biochem Mol Biol. 1991;100(4):801-804.

42. Ekin İ, Başhan M, Seșen R. A comparison of the fatty acid composition of the phospholipid and neutral lipid of Unio elongatulus(Bourguignat, 1860) (Bivalvia: Unionidae) mussels from 4 different localities in southeastern Anatolia, Turkey. Turk J Zool. 2011;35(6):837-849.

43. Ackman RG, Hooper SN. Non-methylene-interrupted fatty acids in lipids of shallow water marine invertebrates: a comparison of two molluscs with the sand shrimp. Comp Biochem Physiol B Biochem Mol Biol. 1973;46(1):153-165.

44. Uno S, Ji Hyun Y, Kaneniwa M, et al. Lipid class and fatty acid composition of mussel, Mytilus trossulus, in Vancouver Harbour, Environmental Assessment of Vancouver Harbour. Data Report for the PICES Practical Workshop, PICES Scientific Report. 2001;16:43-46. 